\title{
혁신적 금융수단의 무상ODA사업 적용방안 \\ 및 사례분석
}

\section{목차}

I. 서론

1. 연구의 목적 및 배경

2. 사례분석 대상

II. 혁신적 금융수단의 정의

1. 혼합재원 조성

2. 임팩트투자 확대

III. 혁신적 금융수단의 무상ODA사업 적용방안

IV. 팔레스타인 창·취업 지원 프로그램 사례

1. 사업 개요

2. 혁신적 금융수단 적용

V. 결론

\section{I. 서론}

\section{1. 연구의 목적 및 배경}

2015년 UN 총회에서의 지속가능개발목표(Sustainable Development Goals, 이하 SDGs) 출 범을 계기로 17 개의 목표 달성을 위한 개발재원 확보에 대해 국제적 관심과 수요가 증가하고 있 고 2015년 제3차 개발재원 총회 결과문서인 아디스아바바 행동계획(Addis Ababa Action Agenda, AAAA)에는 '민관 파트너십 및 공공·민간 부문의 전문성을 결합시킨 혼합재원 확보'가 
주요 행동계획으로 포함되어 있다. 또한 2016년 OECD 개발협력 보고서1)에서는 혼합재원 조성 및 임팩트투자와 같은 혁신적 금융수단의 활용을 SDGs 달성을 위한 주요수단으로 논하고 있다. 하지만 국제사회에서 동분야 추진전략 및 측정방법은 논의 중에 있으며 국내 무상ODA사업에의 적용사례 또한 찾기 힘든 실정이다. 이에 따라 본 고에서는 혁신적 금융수단 중 무상ODA사업에 적용가능한 혼합재원 조성 및 임팩트 투자를 정의하고 적용가능한 방안을 제시하고자 한다. 그리 고 동 관점에서 $\mathrm{KOICA}$ 가 적용 중인 사례를 분석하여 무상ODA사업과 혁신적 금융수단의 바람직 한 결합에 대해 논의하고자 한다.

\section{2. 사례분석 대상}

$\mathrm{KOICA}$ 개발컨설팅 사업인 “팔레스타인 창-취업 지원 프로그램(2015-2019, 700만 달러)"은 2016년 7월 PM(Project Management Service, 사업기획관리자)2) 선정 후 본격적인 사업을 시 작하였다. 동 사업은 SDGs Goal 83)에 부합하여 팔레스타인 창취업 생태계를 지원하는 사업으로 서 스타트업 단계의 기업들이 주요 수혜자이다.

$\mathrm{PM}$ 의 과업범위에 개발재원 활용이 포함되어 있으며 Paltel, Welfare Association 등 현지 민 간 기관들과의 공동펀딩을 통한 매칭사업, 수혜기업들의 투자촉진을 위한 임팩트투자 펀드 설정 등 혁신적 금융수단 적용이 추진되고 있다. 기업이 주요 수혜자인 만큼, 혁신적 금융수단이 적용 되었을 때 기타 ODA 사업에 비해 개발효과성이 높을 것으로 예상되고 있다.

\section{II. 혁신적 금융수단의 정의}

혁신적 금융수단은 저자가 명명한 개념으로서 개발협력 관점에서 외부 투자4)를 유치할 수 있 는 금융 수단을 의미하며 전통적 금융수단과의 차이점은 투자자가 적정수익 뿐만 아니라 개도국 내 사회·환경 등의 임팩트를 동시에 추구한다는 점이다. 혼합재원 조성 및 임팩트 투자가 이에 해당된다고 할 수 있다.

1) OECD. 2016. "Development Co-Operation Report 2016: The Sustainable Development Goals as Business Opportunities". Paris: OECD

2) 삼정회계법인이 선정되었고 벤처투자/엑셀레이팅 및 기술상업화 전문가, 중소기업 정책 전문가가 포함됨

3) 포괄적이며 지속가능한 경제성장과 완전하고 생산적인 고용, 그리고 모두를 위한 양질의 일자리 제공(promote sustained, inclusive and sustainable economic growth, full and productive employment and decent work for all)

4) 외부투자는 저자가 명명한 개념으로서 임팩트 투자의 공공·민간·자선적 투자 유치와 동일 선상에 있으며 혼합재원 조성 의 목적인 민간투자 유치를 포함하는 광의의 개념으로 사용함 


\section{1. 혼합재원 조성}

$\mathrm{OECD}$ 와 세계경제포럼(World Economic Forum, 이하 WEF)은 혼합재원 조성(blended finance) 을 '개도국에서의 민간자본 유치를 위한 공공 개발재원 및 자선기금의 전략적 사용'이라고 정의하 였다(OECD\&WEF, 2015),

혼합재원 조성의 3 대요소는 공공 개발재원과 자선기금이 민간자본을 유인하는 레버리지 (leverage), 사회·환경·경제적 진보 달성에 기여하는 임팩트(impact), 민간투자자가 감당하는 리 스크 수준에 합당한 수익(returns)으로 구성되며 증여·보증·융자·지분투자가 주요 금융수단으로 사용된다(OECD\&WEF, 2015).

혼합재원 조성과 흔히 혼동하기 쉬운 개념이 민관협력(Public Private Partnerships, 이하 $\mathrm{PPPs}$ )인데 PPPs는 혼합재원 조성의 하위개념으로서 도로 등과 같이 공공이 책임지는 영역에 대 한 민간참여를 의미하고, 혼합재원 조성은 제조업등과 같이 공공이 책임지지 않는 영역에 대해서 도 민간 참여를 위한 공공재원(public support)을 투입한다(OECD\&WEF, 2015). 때문에 혼합재 원 조성은 PPPs보다 광의의 개념이며 기존 금융용어로는 대체하기 힘든 새로운 개념이라 할 수 있다.

혼합재원 조성을 전통적 무상ODA사업에서의 민관 협력 사업과 비교시 가장 큰 차이점은 민간 투자자에 대한 적정수익이라고 판단된다. 공공 개발재원과 비영리 재단 또는 대기업의 기업의 사 회적 책임(Corporate Social Responsibility, 이하 CSR) 자금이 결합된 전통적 민관협력 사업에 서 민간 참여자들은 주로 자선적 목적으로 자금을 증여(grants)하고 수익에 대한 기대는 갖지 못 하였다. 그러나 혼합재원 조성 관점의 무상ODA사업은 민간 참여자의 적정수익을 전제 조건으로 하고 있다.

혼합재원 조성을 통한 기대효과는 SDGs 목표 달성을 위한 재원 확대이다. OECD에서는 SDGs 17 개 목표달성을 위해 매년 약 4.5조 달러(약 4,500조 원)의 투자가 2015년 2030년까지 개도 국 내에서 필요할 것으로 예측하였으며 $\mathrm{UNCTAD}$ 는 현재 수준에서 $\mathrm{SDGs}$ 관련 중요 분야 투자 규모는 약 1.4 조 달러로 매년 3.1조 달러의 투자 격차가 발생하는 것으로 보고 있다(오수현, 2016). 혼합재원 조성을 통해 민간투자자를 유입할 경우 이러한 투자 격차를 줄일 수 있을 것으 로 예상된다. 
〈표 1〉 관점에 따른 무상ODA 민관협력사업 비교

\begin{tabular}{c|c|c|c}
\hline \multicolumn{2}{c|}{ 분류 } & 기대수익 & 금융수단 \\
\hline \multirow{2}{*}{$\begin{array}{c}\text { 전통적 무상ODA } \\
\text { 민관협력사업 }\end{array}$} & 공공 & 없음 & 증여 \\
\cline { 2 - 2 } $\begin{array}{c}\text { 혼합재원 조성관점 } \\
\text { 무상인 } \\
\text { 민관협력사업 }\end{array}$ & 공공 & 없음 & 증여 및 보증 등 \\
\cline { 2 - 4 } & 민간 & 위험대비 적정수익 & 지분투자 및 자금융자 등 \\
\hline
\end{tabular}

출처: 저자 작성

\section{2. 임팩트투자 확대}

$\mathrm{OECD}$ 는 임팩트 투자(social impact investment)를 '측정가능한 사회·환경 임팩트(impact)와 재무수익을 동시에 달성하는 비즈니스에 대한 공공·민간·자선 기금의 투자라고 정의하였다 (OECD, 2015).

전통적 투자는 주주가치의 극대화 즉 수익의 극대화를 목표로 삼고 있는 반면 임팩트 투자는 재무수익뿐만 아닌 사회·환경적 임팩트를 동시에 추구한다. 혼합재원 조성과 임팩트 투자는 수익 뿐만 아니라 사회·환경적 임팩트를 동시에 추구한다는 점에서 공통점이 있다. 개발협력 관점에서 해석해 보면 투자자가 재무수익 뿐만 아니라 수원국의 지속가능한 경제·사회발전을 목적으로 투 자를 실행하는 것을 의미한다. 때문에 $\mathrm{OECD}$ 에서는 혼합재원 조성과 함께 임팩트 투자를 SDGs 달성을 위한 비즈니스적 접근방법 5가지5)에 포함하였다.

임팩트 투자의 주요 금융수단은 조성된 임팩트펀드를 기반으로 한 지분투자 또는 자금융자가 주류를 이루지만 최근엔 사회성과 연계채권(Social Impact Bond, 이하 SIB), 개발성과 연계채권 (Development Impact Bond, 이하 DIB)등의 혁신적 상품도 증가하고 있다.

2014년 미국개발청(United States Agency for International Development, 이하 USAID) 과 영국국제개발처(Department for International Development, 이하 DFID)등 선진공여기관 들도 사회혁신펀드(social innovation fund)를 공동출자해 임팩트투자펀드를 조성하는 등 개발협 력에서의 동 분야 적용은 확대되고 있다.

5) 5pathwats : Foreign Direct Investment, Blended Finance, Monitoring and measuring private funds mobilised, social impact investment, Responsible business conduct 
〈표 2〉 전통적 투자와 임팩트투자와의 비교

\begin{tabular}{|c|c|c|}
\hline 구분 & 전통적 투자 방식 & 임팩트투자 방식 \\
\hline 투자목표 & 기업가치(주주이익) 극대화 & $\begin{array}{l}\text { 재무적·사회적 성과 추구 } \\
\text { (두 가치 모두를 극대화하고자 하는 것은 아님) }\end{array}$ \\
\hline 투자주체 & 기금, 투자은행, 개인투자자 등 & 정부, 기금, 투자은행, 재단, 개인투자자 등 \\
\hline 투자대상 & 모든 영역 & 모든 영역(단, 시장실패가 나타나는 영역에 주로 관심) \\
\hline 목표수익률 & $\begin{array}{l}\text { 시장수익률 이상 추구 } \\
\text { (단기수익률 추구 경향) }\end{array}$ & $\begin{array}{l}\text { 시장수익률을 추구하나, 특정 투자자는 시장수익률 } \\
\text { 이하도 용인 }\end{array}$ \\
\hline 수익분배 & 이자, 배당 등 & 이자, 배당 등 \\
\hline
\end{tabular}

출처: KOICA (2014)

\section{개

\section{III. 혁신적 금융수단의 무상ODA사업 적용방안}

무상ODA사업 공공 개발재원에 혁신적 금융수단을 적용하여 외부 투자를 유인하고 개도국 경 제·사회 발전에 기여하기 위해선 많은 고민이 필요하다. 특히, 선진공여국을 포함한 다수의 국가 들이 수년 전부터 혁신적 금융수단을 활용해 개발재원 확대를 추진하고 있고, SDGs 달성을 위한 다양한 주체의 참여와 민간재원 동원의 필요성에 대한 국제적인 공감대가 형성되고 있다. 우리나 라도 전통적인 개발협력 수단 및 재원동원 방식에서 벗어나 개도국 개발 효과 창출이라는 종국의 목적을 달성하기 위해 개발협력 사업에 혁신적 금융수단 도입이 그 어느 때보다 필요한 상황이다.

이러한 환경 변화를 반영하여 무상ODA사업에 적용가능한 혁신적 금융수단에 대해 제시하겠 다. 무상ODA사업의 공공 개발재원은 그 자금의 특성상 증여(grants)사업이 대부분이다. 이때 개 발효과성을 향상시킬 수 있는 혁신적 금융수단 적용방안은 다음과 같다.

첫째, 공공 개발재원이 인프라스트럭처(infrastructure, 이하 인프라) 분야 타당성조사(Feasibility Study, 이하 F/S)를 실행하고 외부 투자유치를 통해 본 사업을 실행하는 방안이 있다. KOICA는 2016년부터 인프라 개발컨설팅사업(Development Experience Exchange Program, DEEP)의 투자연계 강화방안 외부 용역6) 종료 후 최종보고서의 제언사항을 실무 적용 중에 있다.

둘째, 공공 개발재원이 개도국에서 지속가능한 비즈니스를 실행하려는 기업에게 증여를 통해 초기자본(seed money)을 제공하여 사업을 진행시키고 이후 외부투자자가 해당기업에 투자를 실 행하는 형태이다. 외부투자자의 자금으로 피투자기업은 개도국 내에서 비즈니스를 확장시키게 되 고 이를 통해 개도국은 경제성장 및 고용 확대 효과를 얻게 되는 것이다. KOICA는 2015년부터

6) “개도국 인프라개발 컨설팅사업 투자연계 강화방안”, 삼정회계법인, 2016년 1월 
개발행동프로그램(Development Action Program, 이하 DAP)의 창의적 가치 창출 프로그램 (Creative Technology Solution, 이하 CTS)을 추진하면서 USAID, 빌\&멀린다 게이츠 재단 (Bill\&Melinda Gates Foundation), 국내 벤처투자기관 등과 파트너십을 맺고 해당기업의 후속 투자유치를 진행하고 있다.

셋째, 공공 개발재원이 임팩트투자기관에게 증여(grants)로 자금을 지원하고 임팩트투자기관이 지분 투자 또는 자금 융자를 실행하는 방법이 있다. 이때 해당 임팩트투자기관에게는 자부담펀드 를 조성하게 하여 개도국에 대한 외부 투자가 유입되게끔 하는 구조다. KOICA는 2015년 민관협 력사업으로 우간다의 망고펀드(Mango Fund)라는 금융기관에 35만 달러를 증여하고 15 만 달러 의 자부담 펀드를 조성하게 하여 우간다 내 중소기업들을 융자지원하고 있다.

넷째, 공공 개발재원으로 지분투자 또는 융자액에 대한 최우선손실자본(first loss capital)을 설정하는 방법이 있다. SDGs 목표 달성을 위해 개도국에 대한 임팩트투자를 장려하는 과정에서 가장 큰 걸림돌은 투자자들의 수익 확보이다. 선진국에 비해 선천적 투자위험(inherent risk)이 높은 개도국 투자를 장려하기 위해선 투자실패시 투자원금의 안전판이 될 수 있는 최우선손실자 본이 필요하다. 무상ODA사업 공여기관이 임팩트투자기관에 대한 증여를 통해 최우선손실자본을 조성하고 투자기관이 외부 투자자를 모집하게 하는 형태이다.

\section{〈표 3〉 무상ODA사업 최우선손실자본 적용시 유의점}

\begin{tabular}{|c|c|}
\hline & 주요 유의사항 \\
\hline $\begin{array}{c}\text { 무상ODA사업 } \\
\text { 최우선손실자본 } \\
\text { 적용시 }\end{array}$ & $\begin{array}{l}\text { - 동수단 적용으로 인해 실제 개도국에 대한 투자총액이 증가하였는가 } \\
\text { - 사업기간동안 손실보전을 청구하지 않은 민간투자 총액이 동손실자본 설정액보다 큰가 } \\
\text { - 공여기관이 임팩트투자기관에게 자금 증여후 운용시, 투자기관에 대한 심사절차 및 사후관 } \\
\text { 리 방안을 적정하게 설계되었는가 } \\
\text { - 투자기관이 금융투자행위를 실행할 수 있을 만큼의 우량한 재무구조와 금융업에 대한 역 } \\
\text { 량을 갖춘 곳인가 } \\
\text { - 공여기관의 손실자본잔액이 '0’이 될 때까지 사업기간이 반영구적으로 연장될 수 있는데 } \\
\text { 이에 대한 사후관리 보고기간이 적정하게 설계되어 있는가 } \\
\text { - 동수단 적용으로 인해 민간투자가 유입되었다는 것을 투자기관-피투자기업간 계약서 등 } \\
\text { 을 통해 증빙 할 수 있는가 } \\
\text { - 기타 투자자 손실 발생의 법적 정의를 명시하였는가 등 }\end{array}$ \\
\hline
\end{tabular}

출처: 저자 작성

이는 일종의 보증(guarantees)이라고 할 수 있으며 1차 투자자의 원금손실이 발생하지 않을시 동펀드의 재원은 유지가 되어 또다른 건의 투자에 대한 손실보증을 통해 지속적인 투자 확대를 기대할 수 있다. 
다만 원금손실보증비율에 대해선 보다 고민이 필요한 부분이다. 보증비율이 과도하게 높을 경 우 최우선손실자본 설정 금액을 감안하였을 때 투자를 유치하더라도 개도국의 추가투자효과 (incremental investment)가 감소하기 때문이다. KOICA 팔레스타인 창·취업 지원 프로그램에 서는 PASS(Palestine Start-up Support Program) 펀드를 통해 자부담펀드 조성 또는 최우선 손실자본을 조성후 투자자를 유치할 계획이 있다.

다섯째, 공공 개발재원이 $\mathrm{DIB}$ 의 정부 역할로 참여하여 조건부 보증을 실행하는 방안이 있다. $\mathrm{DIB}$ 는 〈그림 1〉에 기술되어 있듯 투자자(investors), 정부(government), 중간기관(intermediary), 사업실행기관(service providers)등 다양한 이해관계자로 구성되어 있다. 개도국 내 SDGs를 달 성하기 위한 공공프로젝트를 투자자의 투자금으로 선수행하고, 정부-중간기관-투자자가 사전에 동의한 성과지표에 따라 프로젝트 종료 후 정부가 투자자에 대해 '원금 $+\alpha$ '의 보상을 실행한다. 성과지표는 객관적이고 계량적으로 작성이 되어야 하며 프로젝트 종료 후 성과평가에 따라 투자 자 수익이 달라지게 되며 원금손실 또한 발생할 수도 있다.

\section{〈그림 1〉 DIB사업의 구조}

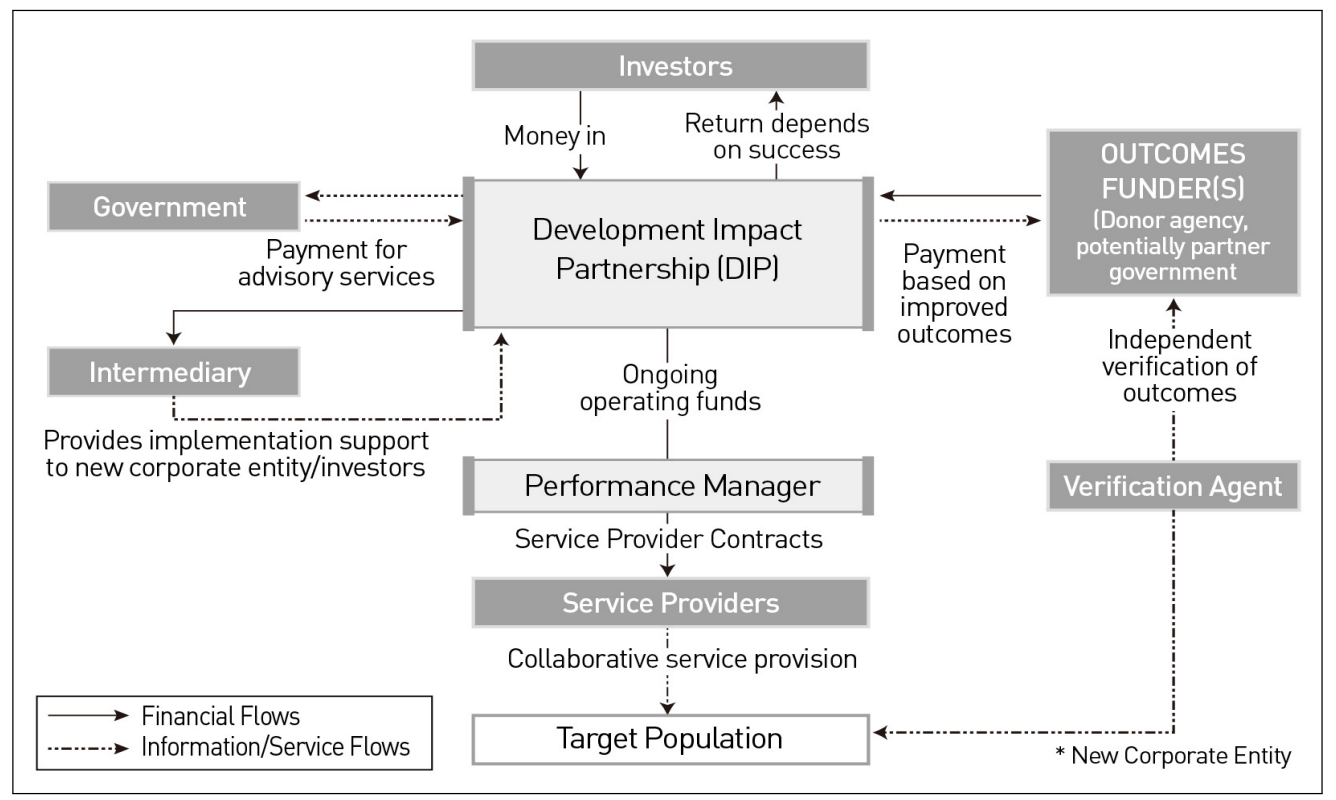

출처: CGD and Social Finance (2013)

$\mathrm{DIB}$ 의 사업발굴 - 정보공유 - 추진방식이나 경험공유 등은 Center for Global Development (CGD)를 중심으로 논의되고 있으며, $\mathrm{CGD}$ 는 영국의 $\mathrm{DFID}$, 미국의 USAID 등 주요 공여기관 및 $\mathrm{DIB}$ 사업을 기획하는 중간기관들의 대표자들로 구성된 DIB작업반(DIB working group)을 운용 
하면서 DIB 관련 정보 및 사례 공유, DIB 연구 보고서 생산, Outcome Fund 등 관련 이니셔티 브 설립 계획 논의를 지속적으로 추진하고 있다 (김지윤·이상준, 2014).

$\mathrm{DIB}$ 적용을 통해 공여기관은 민간투자금을 개도국 내 공공 프로젝트에 유인할 수 있다. 무상 $\mathrm{ODA}$ 사업의 공공 개발재원은 $\mathrm{DIB}$ 구조에서 정부 역할로 참여가 가능하며, 성과가 발생했을 경우 엔 투자자에게 '원금 $+\alpha$ '를 지급하고 성과가 발생하지 않았을 경우엔 보상의 의무 또한 소멸될 수 있다. 이는 조건부 보증이라고 할 수 있다. 이 경우, 공여기관이 중간기관에 자금을 증여하고 'DIB성과보상기금'을 운영하게 함으로써 무상 $\mathrm{ODA}$ 사업의 취지를 충분히 살릴 수 있을 것이다. $\mathrm{KOICA}$ 연구개발팀은 2014년 DIB 적용에 대한 연구를 실행한 바 있다.

상기에서 제시한 무상ODA사업에 적용가능한 혁신적 금융수단을 정리하면 (1) 인프라 $\mathrm{F} / \mathrm{S}$ 투 자연계, (2) 기업에 대한 초기자본 증여후 외부투자 연계, (3) 투자기관에 대한 증여를 통한 간접 투자 및 보증 (최우선손실자본 포함), (4) $\mathrm{DIB}$ 구조에서의 성과기반 조건부보증으로 구성된다.

그러면 상기 4가지 수단을 우리나라 무상ODA 기관인 $\mathrm{KOICA}$ 의 주요사업에 적용해 보겠다. $\mathrm{KOICA}$ 는 프로젝트(개발컨설팅 사업 포함) 사업, 민관협력사업, 연수초청사업, 해외봉사단 파견 사업 등을 주로 실행하고 있고 2015년부터는 DAP사업을 신규 실행하고 있다. 이 중 혁신적 금 융수단이 적용가능한 사업을 정리하면 〈표 4〉와 같다. 상당히 많은 $\mathrm{KOICA}$ 주요사업들에 혁신적 금융수단이 적용가능함을 알 수 있다. 〈표 4〉에는 포함되어 있지 않지만 연수초청 사업 및 해외 봉사단 파견사업을 통해서도 혁신적 금융수단 적용 확대를 위한 교육 및 교류 확대 노력이 가능하다.

$\mathrm{KOICA}$ 는 우리나라의 대표적인 무상ODA 기관으로서 주요 진행사업에 대한 혁신적 금융수단 도입 확대를 통해 외부투자 확보 및 SDGs 달성 가속화에 노력을 기울여야 한다.

〈표 4〉 KOICA 주요사업에 적용가능한 혁신적 금융수단

\begin{tabular}{|c|c|c|}
\hline 사업분야 & $\begin{array}{c}\text { 혁신적 } \\
\text { 금융수단 형태 }\end{array}$ & 적용방안 \\
\hline 인프라 분야 개발컨설팅 사업 & \multirow{4}{*}{$\begin{array}{c}\text { 혼합재원 조성 및 } \\
\text { 임팩트투자 }\end{array}$} & (1) 인프라 F/S 투자연계 \\
\hline $\begin{array}{c}\text { DAP사업 - CTS/개도국 비즈니스 } \\
\text { 기회창출프로그램 }\end{array}$ & & (2) 기업에 대한 초기자본 증여후 외부투자 연계 \\
\hline $\begin{array}{c}\text { 기업비즈니스 분야 개발컨설팅 사업/ } \\
\text { 민관협력 사업 }\end{array}$ & & $\begin{array}{l}\text { (3) 투자기관에 대한 증여를 통한 간접 투자 및 } \\
\text { 보증(최우선손실자본 포함) }\end{array}$ \\
\hline $\begin{array}{c}\text { 프로젝트(개발컨설팅사업 포함), } \\
\text { 민관협력사업, DAP사업 등 주요사업 전반 }\end{array}$ & & (4) $\mathrm{DIB}$ 구조에서의 성과기반 조건부 보증 \\
\hline
\end{tabular}

출처: 저자 작성 


\section{IV. 팔레스타인 창·취업 지원 프로그램 사례}

\section{1. 사업 개요}

‘팔레스타인 창·취업 지원 프로그램(2015-2019, 700만 달러)'은 혁신적 금융수단 중 '(3) 투자 기관에 대한 증여를 통한 간접 투자 및 보증을 적용한 기업 비즈니스 분야 KOICA 개발컨설팅 사업이다. 2016년 7월 PM(Project Management Service, 사업기획관리자)인 삼정회계법인 선 정후 본격적인 사업을 시작하였고 사업 개요는 〈표 5〉와 같다.

〈표 5〉 ‘팔레스타인 창-취업 지원 프로그램' 개요

\begin{tabular}{|c|c|c|c|c|}
\hline 구 분 & \multicolumn{4}{|c|}{ 설 명 } \\
\hline 사업명 & \multicolumn{4}{|c|}{$\begin{array}{l}\text { 팔레스타인 창·취업 지원프로그램 } \\
\text { (Palestine Start-up Support(PASS) Program) }\end{array}$} \\
\hline 수원기관 & \multicolumn{4}{|c|}{ 팔레스타인 정보통신부 } \\
\hline 기간/예산 & \multicolumn{4}{|c|}{ 2015년-2019년/700만 달러 } \\
\hline 대상지역 & \multicolumn{4}{|c|}{ 팔레스타인 서안지구/동예루살렘 지역 및 가자지구 } \\
\hline 사업목표 & \multicolumn{4}{|c|}{ 팔레스타인 스타트업 생태계 성장을 통해 지속가능한 경제발전에 기여 } \\
\hline \multirow{3}{*}{$\begin{array}{l}\text { 사업 } \\
\text { 내용 }\end{array}$} & 지역 & 사업내용 & 추진절차 & 공통 \\
\hline & $\begin{array}{c}\text { 서안지구 } \\
\text { (West Bank), } \\
\text { 동예루살렘 } \\
\text { (East } \\
\text { Jerusalem) } \\
\text { : 570만 달러 }\end{array}$ & $\begin{array}{l}\text { - 창취업 인적역량 강화/산학협력 지원 } \\
\text { - 정부 역량강화 지원 } \\
\text { - 청소년/대학생 창취업 역량강화 교육프로 } \\
\text { 그램 } \\
\text { - 산학협력 프로그램 } \\
\text { - 스타트업 파이프라인 환대 및 투자환경 개선 } \\
\text { - 사업화 아이템 발굴 } \\
\text { - 초기 스타트업 형성 지원 } \\
\text { - 성장단계 스타트업 육성지원 } \\
\text { - 스타트업 투자플랫폼 구축 } \\
\text { - 온라인 플랫폼 구축 }\end{array}$ & $\begin{array}{l}\text { - KOICA 직접수행 } \\
\text { - 입찰을통한 용역 } \\
\text { 업 체 선 정 (PM, } \\
\text { PC) 후 실행 }\end{array}$ & \multirow[t]{2}{*}{$\begin{array}{l}\text { - PM 성과관리 } \\
\text { 및 성과평가 } \\
\text { 실행 }\end{array}$} \\
\hline & $\begin{array}{c}\text { 가자지구 } \\
\text { (Gaza Strip) } \\
: 130 \text { 만 달러 }\end{array}$ & $\begin{array}{l}\text { · 가자지구내 ICT사회적 기업 ‘Gaza Gateway’ } \\
\text { 설립 및 운영지원 }\end{array}$ & $\begin{array}{l}\text { - Multi-bi사업으로 } \\
\text { UNRWA 수행중 } \\
\text { (2015-2017/3년) }\end{array}$ & \\
\hline 진행현황 & \multicolumn{4}{|c|}{ O사업기획관리(PM) 착수조사 출장실행 (2016년 8월) } \\
\hline
\end{tabular}

출처: 저자 작성 


\section{2. 혁신적 금융수단 적용}

동 사업은 〈그림 2〉와 같이 개발 효과성 제고를 위해 현지 국제기구(United Nations Relief and Works Agency for Palestine Refugees in the Near East, 이하 UNRWA), 공여기관 (Belgian Development Agency, 이하 BDA), 대기업(Paltel Group, 이하 PG), 비영리기구 (Welfare Association, 이하 WA) 등 다양한 현지 이해관계자들과 개발효과성 상승을 위해 공식 협업하고 있다. 동사업은 수원국 요청이 아닌 현지 산업 수요를 반영해 팔레스타인 사무소가 주 도적으로 사업을 발굴한 사례로서 다양한 현지 기관들과의 협업도 사무소의 노력이 빚어낸 결과 물이다.

뿐만 아니라 동 사업 구조에는 혼합재원 조성 및 임팩트투자를 활용한, 외부투자를 유치하기 위한 혁신적 금융수단이 포함되어 있다. 초기자금 확보가 중요한 현지 스타트업이 주요 수혜자인 만큼 혁신적 금융수단을 연계하여 개발효과성을 상승시키기 위해 노력하였다.

$\mathrm{KOICA}$ 는 $\mathrm{PG}(\mathrm{KOICA}-\mathrm{PG}$ 각각 50만 달러 투입) 및 WA(KOICA-WA 각각 70만 달러 투입) 와 $1: 1$ 사업비 매칭사업 실행을 위해 협의 중이다. $\mathrm{PG}$ 와의 사업은 청소년 코딩교육(Code for Palestine)과 청소년/대학생 창·취업 기술역량강화 교육(Technical Training), 글로벌창업센터 (Global Innovation Center) 설립 등에 사용하는 것을 논의 중이며 PG의 PASS(Palestine

\section{〈그림 2〉 팔레스타인 창·취업 프로그램 협업구조}

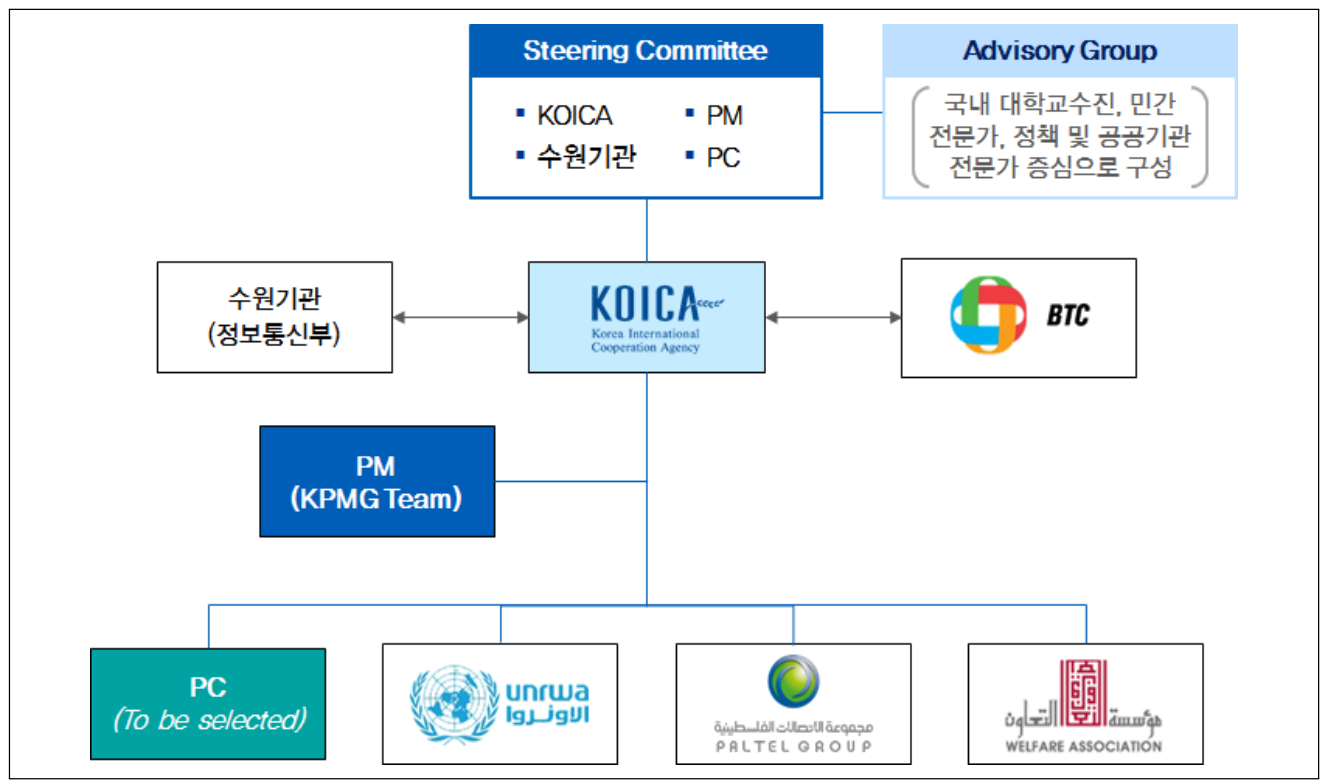

출처: 동사업 착수보고회 PM 발표자료 (2016) 
Start-up Support Program, 이하 PASS) Fund 투자자 참여도 검토 중이다. 이는 혼합재원 조 성의 광의적 개념인 '개도국에서의 민간자본 유치를 위한 공공 개발재원 및 자선기금의 전략적 사 용’에 부합하며 PASS Fund 참여를 통해 PG에게 적정수익을 제공해 주면 혼합재원 조성이 제시하 는 요소들을 모두 갖추었다고 할 수 있다.

WA와의 사업은 그들이 보유한 국외 팔레스타인 엔젤 투자자(angel investors) 네트워크를 확 대 및 활용하는 사업으로서 투자자의 현지 스타트업 투자확대 및 우수 스타트업 발굴을 통한 적 정수익 확보에도 기여할 수 있다. 이사업 또한 혼합재원 조성 개념에 부합하며 WA도 PASS Fund 투자자 참여를 검토하고 있다. 임팩트투자가 적용된 PASS Fund는 〈표 6〉와 같은 운용구 조로 실행될 예정이며 $\mathrm{PC}($ Project Contractor)는 이르면 2016년 12월 결정될 예정이다. KOICA 는 $\mathrm{PC}$ 에게 자금을 증여하여 펀드의 기초재원을 마련할 예정이며 이를 통해 $\mathrm{PM}$ 및 $\mathrm{PC}$ 는 $\mathrm{KOICA}$ 외 투자자를 유치할 예정이다. 그리고 자금을 $\mathrm{KOICA}$ 로부터 증여받은 $\mathrm{PC}$ 는 투자를 직접 집행하 거나 최우선손실자본(first loss capital)을 조성하여 투자를 유치할 계획이다. 두가지 방법론 중 투자금을 더 많이 확보할 수 있는 방안을 고민하여 실행 예정이며 $\mathrm{KOICA}$ 는 ‘표 3〉 최우선손실 자본의 무상ODA사업 적용시 유의점'을 검토 확인 후 $\mathrm{PC}$ 와 약정을 체결 예정이다.

동사업은 혁신적 금융수단이 무상 $\mathrm{ODA}$ 사업이 적용되어 외부투자의 유입 및 수혜 스타트업의 성장, 궁극적으로 SDG 8의 달성을 촉진할 수 있는 모범사례라고 판단된다.

〈표 6〉 PASS Fund 운용구조

\begin{tabular}{|c|c|c|c|}
\hline 실행주체 & 기관형태 & 임팩트투자 적용 관점에서의 역할 & 목 적 \\
\hline KOICA & $\begin{array}{l}\text { 무상ODA } \\
\text { 공여기관 }\end{array}$ & - PC에게 증여(grants)를 통해 자금 지급 & \multirow{3}{*}{$\begin{array}{c}\text { 외부투자 } \\
\text { 유치를 통한 } \\
\text { 수혜기업 } \\
\text { 성장 및 } \\
\text { SDGs 달성 } \\
\text { 촉진 }\end{array}$} \\
\hline $\begin{array}{l}\text { PM } \\
\text { (project management } \\
\text { service) }\end{array}$ & $\begin{array}{l}\text { 글로벌 회계/ } \\
\text { 컨설팅법인 }\end{array}$ & $\begin{array}{l}\text { - KOICA외 펀드투자자 모집 총괄 } \\
\text { - PC의 금융투자행위 관리·감독 및 KOICA에 대한 보고 }\end{array}$ & \\
\hline $\begin{array}{c}\text { PC } \\
\text { (project contractor) }\end{array}$ & $\begin{array}{c}\text { 현지 } \\
\text { 엑셀레이터/ } \\
\text { 투자기관(미정) }\end{array}$ & $\begin{array}{l}\text { - KOICA에게 증여 받은 자금을 바탕으로 지분투자 실행 } \\
\text { 또는 최우선손실자본 펀드 설정후 운용 } \\
\text { - KOICA외 펀드투자자 모집 }\end{array}$ & \\
\hline
\end{tabular}

출처: 저자 작성 


\section{V. 결론}

국제사회 뿐만 아니라 국내에서도 SDGs 달성을 위한 개발재원 확보 노력은 가속화되고 있다. 특히, SDGs 달성을 위해 필요로 하는 개발재원 규모가 기존 공공재원만으로 충당하기 어려울 뿐 만 아니라 공공재원의 확대에도 많은 제약이 따르므로 민간재원의 동원은 불가피한 실정이다. 무 상ODA 사업도 이러한 경향을 반영하여 지속가능한 외부투자를 유치하기 위한 노력들이 필요할 것으로 판단된다.

우선, 혁신적 금융수단을 적극적으로 활용할 필요가 있다. 본문에서 기술한 바와 같이 혼합재 원 조성 및 임팩트 투자 등을 통해 투자자에게 적정수익을 확보해 주면 신규 투자자 유입 및 투 자 회수를 통한 총재원 증가 효과를 동시에 달성할 수 있다. 이때 실행 방안은 (1) 인프라 F/S 투 자연계, (2) 기업에 대한 초기자본 증여 후 외부투자 연계, (3) 투자기관에 대한 증여를 통한 간접 투자 및 보증(최우선손실자본 포함), (4) $\mathrm{DIB}$ 구조에서의 성과기반 조건부보증으로 구성될 수 있 다. 다만 투자기관에게 자금을 증여 후 실행할 경우에는 반드시 적정한 심사절차 및 사후관리 약 정이 전제되어야 한다.

또한, 공여기관들 간 협력이 제고될 필요가 있다. 혼합재원 조성 및 임팩트투자 관점에서 투자 자는 사회적 임팩트뿐만 아니라 적정수익을 목표로 하고 있는 반면 공여기관은 무유상의 자금 성 격을 떠나 SDGs 달성을 주목적으로 하고 있다. 때문에 공여기관들 간 공동사업 설계를 통해 대 규모 투자자들을 유치하기 위한 노력이 필요하다. $\mathrm{KOICA}$ 팔레스타인 창·취업 지원 프로그램에 서는 BTC와의 협업을 통해 총사업비의 효율화 및 PASS Fund에 대한 투자자 유치 가능성 확대 까지 기대하고 있다.

무상ODA사업에서의 혁신적 금융수단 적용은 외부투자 유입을 통한 재원 확보 뿐 아니라 시장 진출 대상국으로서의 개도국에 대한 관심과 참여를 높일 수 있다. 개도국에 대한 관심 증대는 현 지에서의 비즈니스 기회 창출 및 고용 확대 등으로 연결될 수 있고 이는 개도국 내 지속가능한 경제성장의 밑거름이 될 것으로 예상된다.

무상ODA사업의 혁신적 금융수단 적용은 아직 초기인 만큼 외부투자자의 자발적인 참여 환경 이 조성되기 전까지는 공여기관의 많은 노력이 필요하다. 공여기관은 타 공여기관 및 국내외 잠 재투자기관과의 파트너쉽을 통해 모든 이해관계자의 니즈를 충족시켜주는 금융구조 및 수단에 대 해 지속적인 고민을 실행해야 한다. 외부투자자들이 ODA사업을 통해 재원의 지속가능성 및 개도 국내 사회 임팩트 확대에 대해 확신한다면 SDGs 달성 또한 가속화될 수 있을 것이다. 


\section{〈참고문헌〉}

김성우·김승현·이규민. 2016. "한국국제협력단(KOICA) 팔레스타인 창·취업 지원프로그 램 사업기획관리(PM)용역 착수보고회 발표자료”. 서울: 삼정회계법인 김지윤·이상준. 2014.『임팩트투자 및 $\mathrm{DIB}$ 논의와 시사점』. 성남: 한국국제협력단 오수현. 2016. "Post-2015 체제의 개발재원 논의분석". 성남: 한국국제협력단

CGD· Social Finance. 2013. "Investing in Social Outcomes: Development Impact

Bonds". Center for Global Development-Social Finance, available at http://www.cgdev.org/publication/investing-social-outcomes-development-im pact-bonds (접속일: 2016.09.19)

OECD -World Economic Forum. 2015. "Blended Finance Vol.1: A Primer for Development Finance and Philanthropic Funders". Geneva: World Economic Forum, available at https://www.weforum.org/reports/blended-finance-toolkit (접속일: 2016.09.19)

OECD. 2016. "Development Co-operation Report 2016: The sustainable development goals as business opportunities". Paris: OECD publishing, available at http://www.oecd.org/dac/development-co-operation-report-20747721.htm (접속일: 2016.09.19) 